\title{
Comparison in Lymphocyte Subpopulation between Arterial and Venous Bloods of Rat
}

\author{
Tetsuo KUNIEDA, Tsutomu KUROSAWA*, Yoshihiro SUGIYAMA*, \\ Hitoshi HANAUE*, Tomonori IMAMICHI** and Jun-ichi SHIKATA*
}



(Received 8 October 1985/Accepted 12 November 1986)

Lymphocyte subpopulation as well as other hematological properties were compared between arterial and venous bloods of Wistar-Imamichi rats. Lymphocyte subsets were defined with four monoclonal antibodies which were specific to the respective cell surface glicoproteins. Using these monoclonal antibodies, subsets of B lymphocytes, $T$ lymphocytes, helper $\mathrm{T}$ lymphocytes, and supressor and cytotoxic $\mathrm{T}$ lymphocytes in the peripheral lymphocytes were identified. The blood samples were taken from aorta abdominalis and venae cava caudalis. The population of these subsets were enumerated by a laser flow-cytometry system. The result showed that there was no significant difference in hematological properties between the arterial and venous blood except in leukocyte count and hemoglobin concentration. The difference in leukocyte counts was thought to depend mainly on the fluctuation of the lymphocyte counts. However, no significant difference was recognized in the proportion of positive cells to each monoclonal antibody. It was concluded that the difference in leukocyte counts found between the arterial and venous bloods of the Wistar-Imamichi rat did not produce any effects on the proportion of the subpopulation in the peripheral lymphocytes, and the lymphocyte subpopulations in both arterial and venous bloods were substantially equivalent to each other.

\section{ラットに拈ける動脈血, 静脈血間のリンパ球$$
\text { サブポピュレーションの比較 }
$$

国枝哲夫・黒澤努*.杉山芳宏*. 花上 伴*.今道友則**.四方淳一* 財団法人動物繁殖研究所

* 帝京大学医学部第一外科

** 日本獣医畜産大学生理学教室

動物における一般的な血液学的検査では, 採血部位の 相違が種々の測定値に影響を与えることが知られてい
る。特に白血球は, 体内における動態が赤血球などに比 ベて複雑であり, ラットについてあ採血部位によってそ 
の数は大きく変化する。したがって, 採血部位の違いが リンパ球サブポピュレーションにどのような影響をあた えるかを明らかにするため，モノクローナル抗体および レーザーフローサイトメトリーをもちい, 測定の諸条件 を検討するとともに，Wistar-Imamichi ラットにおけ る動脈血と静脈血の血液学的性状とリンパ球サブポピュ レーションの比較を行った。

\section{材料と方法}

1. 動物：動物は, 財団法人動物繁殖研究所（土浦研 究所）にて繁殖, 飼育されているWistar-Imamicni ラ ットの 6 週龄雄11匹を用いた。

2. 飼育環境: Barrier System による飼育条件下で, 室温 $24 \pm 1{ }^{\circ} \mathrm{C}$, 湿度 $50 \sim 60 \%$, 換気问数 1 時間に約 13 回 (HEPA フィルターでろ過した清浄空気)，照明時間14 時間（午前 5 時〜午後 7 時点灯）に設定された動物室で 飼育した。飼料は標準配合飼料 [22]，および 固 形 飼料 $\mathrm{MM}-2$ (船橋農場) を高圧蒸気滅菌器を用い $120^{\circ} \mathrm{C}$ (圧力 $1.2 \mathrm{~kg} / \mathrm{cm}^{2}$ ) で20分間滅菌し，2：1 で混合したものを 給与した。飲水は60分間高圧蒸気堿菌したものを自由に 摄取させた。

3. 採血方法：動物をペントバルビタールナトリウム の腹腔内注射 $(6 \mathrm{mg} / 100 \mathrm{~g}$ 体重) にて麻酔し開腹の後, まず後大静挀の左㛑静脈分枝部より，デスポーザブル注 射器を用いて $2 \mathrm{~m} l$ 採血し, 静脈血とした。ついで腹部 大動派より $2 \mathrm{ml}$ 採血し, 動脈血とした。抗凝固剂は 5 \% EDTA-2K 溶液を用い, あらかじめ採血用の注射器 に約 $0.1 \mathrm{~m} l$ を吸引しておいた。

4. 血液学的検査：赤血球数および白血球数は, 採血 された血液を希釈液 CK-32（東亜医用電子）にてそれ ぞれ50,000倍，および500 倍に希釈した上で，トーア自 動血球計数装置 CC-108（東亜医用電子）を用いて測定 した。ヘマトクリット值および平均赤血球容積 (MCV) は，トーア MCVへマトクリット測定装置 MH-301（東 亜医用電子）を用いて，電気抵抗方式にて測定した。へ モグロビン濃度は，トーア自動血色素濃度测定装置 HB -100（東垔医用電子）を用い，シアントへモグロビン法 には測定した。白血球百分率は採血時に作製した叙抹標 本をメタノール固定の後, Giemsa 染色によって染色し, 顕微鏡下で算定した。

5.リンパ球サブポピュレーションの測定：

a ）モノクローナル抗体：ラットリンパ球サブッセッ トの同定には，各サブセットに特異的な 4 種のモノクロ
一ナル抗体 MAS 010, MAS 1131, MAS 041, MAS 029 (Sera-lab 社) を用いた。これらのモノクローナル 抗体は, W3/13, W/25, OX8, OX4 の各クローンより 産生されており，いずれあ IgG である。

各モノクローナル抗体の特性は以下のと抢りである。



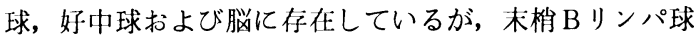
に存在していないことが報告され[24], 末梢リンパ球の うちW3/13モノクローナル抗体に陽性の細胞は Tリンパ 球であると考えられている。

W3/25抗体に対する抗原は, 胸腺細胞, マクロファー ジおよび末梢 Tリンパ球の一部に存在していることが報 告され $[15,24]$, 末梢リンパ球のうち, W3/25モノクロ 一ナル抗体に陽性の紐胞は, ヘルパーTリンパ球と考え られている $[15,23]$ 。

OX8 抗体に対する抗原は胸腺細胞, 末梢 Tリンパ球 の一部, および $\mathrm{NK}$ 細胞の大部分に存在していること が報告され $[3,6]$, 末梢リンパ球のうち, OX8 陽性紏 胞はサプレッサーおよび細胞障害性 Tリンパ球であると 考えられている $[3,7,15]$ 。

OX4 抗体に対する 抗原は, 主要組織適合系遺伝子複 合体 (MHC) のクラスI抗原である Ia 抗原（I 領域関

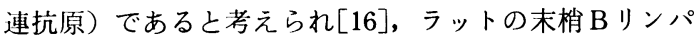
球の大部分に存在し, 胸腺紏胞, マクロファージの一部 にも存在するが，末佾 Tリンパ球には存在しないことが 知られている $[2,16]$ 。したがって，末梢リンパ球のう ち, OX4 陽性紏胞は B リンパ球であると考えられる。

b ）サンプルの調整：レーザーフローサイトメトリー のためのサンプルの調整は, 従来の方法[19]に若下の変 更を加え以下の方法で行なった。

全向 $100 \mu \mathrm{l}$ に, PBS $\left(\mathrm{Ca}^{2}, \mathrm{Mg}^{2}\right.$ 不含, ph 7.4-7.6) にて50倍希釈したモノクローナル抗体 $100 \mu \mathrm{l}$ を加え， 4 ${ }^{\circ} \mathrm{C}$ で30分間放置した。その後 PBS で 2 回洗浄し, 二次 抗体として 40 倍希积した Fluorescein Isothiocyanate (FITC) 標識ヤギ抗マウス IgG 抗体 (Tago 社) $100 \mu l$ を加え，さらにラットの血しょう $25 \mu l$ を加えて， $4{ }^{\circ} \mathrm{C}$ で30分間放置した。再び PBS で洗浄した後, Fetal Calf Serum (Filton 社) $5 \mu l$ を加えたうえで溶 血剂 $\left(\mathrm{NH}_{4} \mathrm{Cl} 4 \mathrm{~g} / l, \mathrm{KHCO}_{3} 1 \mathrm{~g} / l\right.$, EDTA-4 Na 0.037g/l) $2 \mathrm{~m} l$ を加え, 室温で $3 \sim 5$ 分間放置した後に測定した。 陰性コントロールには, 上記モノクローナル抗体の代り に，20倍希釈したマウス IgG (Cappel 社)を用いた。

c ) フローサイトメリーシステム：サンプルの測定に はレザーフローサイトメトリーシステム,オーソスペク 
トラムIII（オーソダィアグノスティックシステムズ社）

を用いた $[19]$ 。

細胞の光学的情報としては, 前方散乱光, $90^{\circ}$ 散乱光, 波長 515〜620nm の緑色蛍光の 3 つのパラメータを用い た。

d）測定方法：オーソスペクトラムIIIを用いての測定 は以下の手順で行った。

前方散乱光と $90^{\circ}$ 散乱光をパラメーターとするサイト グラムを表示させ, サイトグラム上で，いくつかに分離 した紐胞集団のうち, リンパ球を表す細胞集団について のみ蛍光強度を测定した。その結果をX軸を蛍光強度と し，Y軸を細胞数としたヒストグラムとして出力し，細 胞自体の非特異的蛍光を, モノクローナル抗体による特 異的な蛍光と区別するために，陰性コントロールにおい て, 陽性領域の細胞が全細胞数の $1 \%$ 以下となるように 陽性領域を設定し, この条件を用い, 各モノクローナル 抗体で調整されたサンプルの陽性細胞の全細胞に対する 比率を測定した。

6. 統計学的処理：測定した值について, 対応する 2 試料間の $\mathrm{t}$-検定 (Paired sample $\mathrm{t}$-test) を用い, 動, 静脈血間の差を検定した。

\section{成 績}

各個体より得られた動脈血, 静脈血について測定した 赤血球数, ヘマトクリット值, MCV, ヘモグロビン濃 度を Table 1 に示した。赤血球数へマトクリット值, $\mathrm{MCV}$, ヘモグロビンの各測定值とも, 動脈血と静脈血 の間には有意の差は認められなかった。白血球数, およ び白血球百分率を Table 2 に示した。白血球数は, 動 脈血が $2.55 \pm 0.93 \times 10^{3} / \mu l$, 静脈血が $4.52 \pm 1.09 \times 10^{3} /$ $\mu l$ であり, 静脈血の值が動脈血の值に比較し有意に高か った $(\mathrm{p}<0.01)$ 。リンパ球数は, 動脈血が $1.97 \pm 0.74 \times$ $10^{3} / \mu l$, 静脈血が $3.84 \pm 1.02 \times 10^{3} / \mu l$ であり,やはり静



Fig. 1. A laser flow-cytometry system used.

Cells traveled through a flow channel are iluminated by focused argon laser beam. Light scattered by the cells is collected in forward and right-angle directions. the fluorescent light emitted from the cell are measuaed by a detecter positioned at a right-angle.

脈血の值が動脈血の值に比較し有意に高かった $(\mathrm{p}<$ 0.01)。また, 単球でも, 動脈血が $0.06 \pm 0.02 \times 10^{3} / \mu l$, 静脈血が $0.09 \pm 0.03 \times 10^{3} / \mu l$ であり, 静脈血の值が動脈 血の值に比較し有意に高かった $(\mathrm{p}<0.05)$ 。好中球, 好 酸球, 好塩基球数は, 動脈血, 静脈血間に有意の差は認 められなかった。

レザーフローサイトメトリーより得られたサイトグラ ムを, Fig. 2 に示した。各サンプルとも Fig. 2-1) と 同様のサイトグラムが得られ，血球は A, B， C, Dの 4 クラスターに分離した。また, 従来の方法[19]でサン プルを調整したところ, Fig. 2-2) に示したように，サ イトグラム上での各クラスターの分離は困難であった。

次に，サイトグラム上のAクラスターをリンパ球を表 す集団とし，Aクラスターに含まれる細胞のみについ

Table 1. RBC, $\mathrm{Ht} \mathrm{Hb}$, and MCV of arterial and venous bloods in Wistar-Imamichi rat

\begin{tabular}{lcccc}
\hline & $\mathrm{RBC}\left(\times 10^{6} / \mathrm{mm}^{3}\right)$ & $\mathrm{Ht}(\%)$ & $\mathrm{Hb}(\mathrm{g} / \mathrm{d} l)$ & $\mathrm{MCV}(\mathrm{f} l)$ \\
\hline Arterial blood $^{1)}$ & $5.88 \pm 0.82$ & $38.0 \pm 7.0$ & $11.3 \pm 2.1$ & $61.4 \pm 3.4$ \\
Venous blood $^{2)}$ & $6.19 \pm 1.35$ & $36.5 \pm 4.6$ & $11.3 \pm 0.9$ & $61.6 \pm 3.2$ \\
\hline
\end{tabular}

All values are expressed as Mean \pm S. D. of 11 rats.

1) Arterial blood was taken from aorta abdominalis.

2) Venous blood was taken from venae cara caudalis.

No significant difference recognized betwee arterial and venous bloods.

$P$ values were determind by paired sample t-test. 

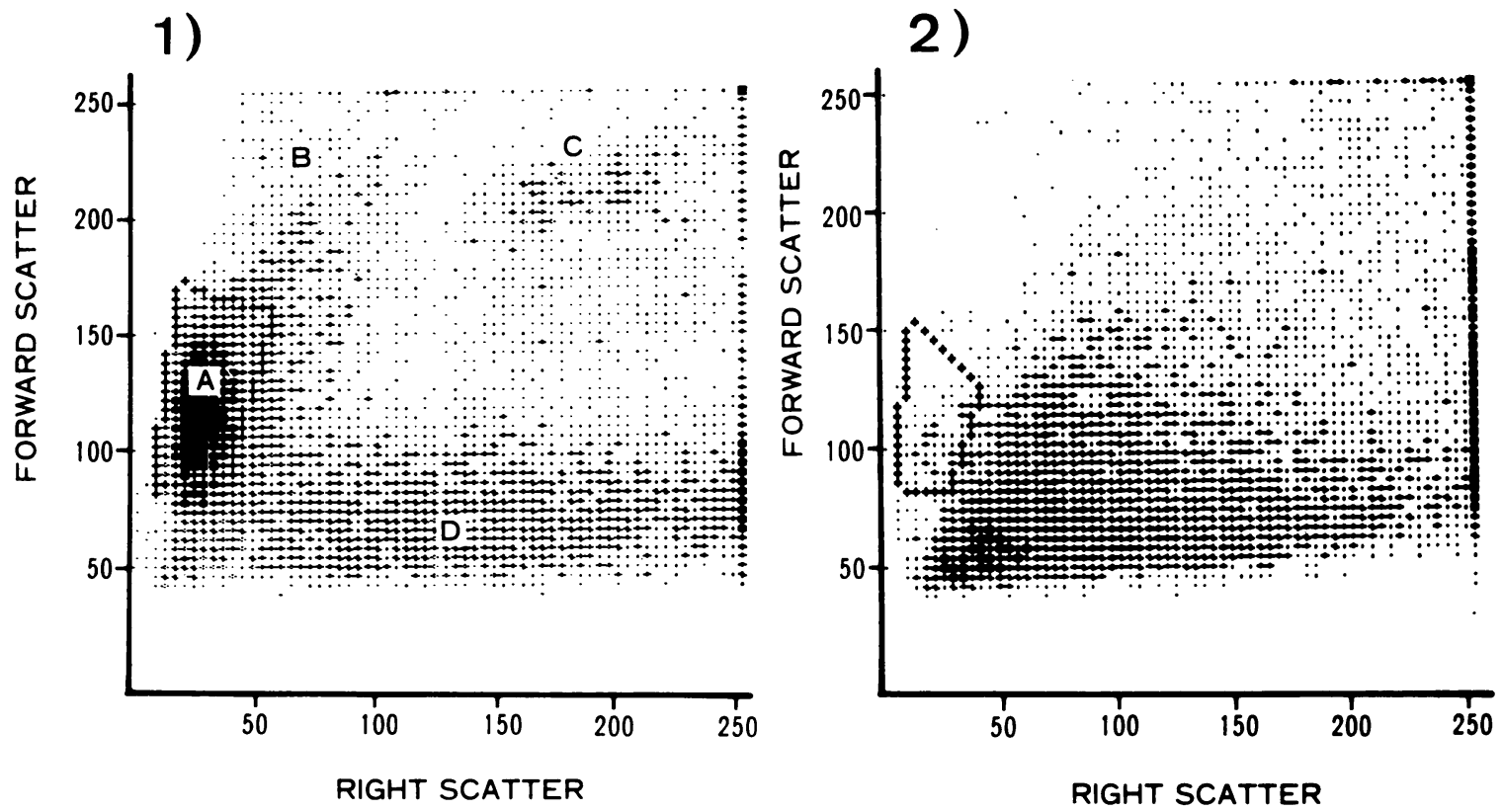

Fig. 2. Two-dimensional cytograms from Orthe Spectrum III

Right-angle v. s. forward narrow-angle scatterd light of rat leukocytes.

1) A cytogram obtained from the sample prepared by a modified method as described.

2) A cytogram obtaened from the sample prepared by a conventional method.

The four clusters represent:

A, lymphocytes; B, monocytes; C, granulocytes; and D, erythrocytes and platelets.

A gate window (marked in + ) is provided to deflne cluster A.

Table 2. Total and differential leukocyte counts of arterial and venous bloods in Wistar-Imamichi rat

\begin{tabular}{|c|c|c|c|c|c|c|}
\hline & \multirow{2}{*}{ WBC $\left(\times 10^{3} / \mu l\right)$} & \multicolumn{5}{|c|}{ Differential Leukocyte Counts $\left(\times 10^{3} / \mu l\right)$} \\
\hline & & Neutrophils & Lymphocytes & Monocytes & Eosinophils & Basophils \\
\hline Arterial & $2.55 \pm 0.93^{* *}$ & $0.51 \pm 0.20$ & $1.97 \pm 0.74^{* *}$ & $0.06 \pm 0.02 *$ & $0.01 \pm 0.02$ & N. D. \\
\hline Blood ${ }^{1)}$ & & $(20.0 \pm 3.4 \%)$ & $(76.8 \pm 4.1 \%)$ & $(2.8 \pm 1.6 \%)$ & $(0.4 \pm 0.6 \%)$ & \\
\hline Venous & $4.52 \pm 1.09 * *$ & $0.61 \pm 0.19$ & $3.84 \pm 1.02 * *$ & $0.09 \pm 0.03^{*}$ & $0.01 \pm 0.02$ & N. D. \\
\hline Blood $^{2)}$ & & $(14.45 \pm 5.3 \%)$ & $(84.4 \pm 4.5 \%)$ & $(2.1 \pm 0.8 \%)$ & $(0.2 \pm 0.3 \%)$ & \\
\hline
\end{tabular}

All values are expressed as Mean \pm S. D. of 11 rats. N. D. - Not detected.

1) Arterial blood was taken from aorta abdominalis.

2) Venous blood was taken from venae cava caudalis.

* Significant difference recognized between arterial and venous bloods. $(p<0.05)$

** Significant difference recognized between arterial and venous bloods. $(p<0.01)$

$\mathrm{P}$ values were determind by paired sample $\mathrm{t}$-test.

て，蛍光強度をパラメーターとして得られたヒストグラ

ムを Fig. 3 に示した。これらのヒストグラムのプロフ ィールに，各サンプルとあ同様であった。

フローサイトメトリーにて測定した, 各モノクローナ ル抗体と反応させたサンプルにおける, 全リンパ球中の
陽性細胞の比率求よび，W3/25陽性細胞とOX8 陽性細 胞との比を Table 3 に示した。動脈血および静脈血の 各モノクローナル抗体に対する陽性細胞の比率は, W3/

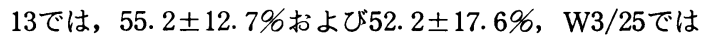
$43.5 \pm 9.2 \%$ および $39.7 \pm 10.9 \%, \mathrm{OX} 8$ では $13.9 \pm 4.9$ 
Table 3. Percentages of lymphocytes, obtained from arterial and venous bloods, labelled byW3/13, $\mathrm{W} 3 / 25$, OX4, and OX8 mouse anti-rat monoclonal antibodies, and ratio of $\mathrm{W} 3 / 13 / \mathrm{OX} 8$



\%および $13.3 \pm 3.6 \%, \mathrm{OX} 4$ では $37.4 \pm 5.9 \%$ および $42.2 \pm 8.6 \%$ であり，それぞれ動脈血と静脈血の間で有 意の差は認められなかった。また，W3/25 陽性細胞と OX8 陽性細胞の比においても，有意の差は認められな かった。

\section{考 察}

白血球数が動静脈血間で有意に差があることに関し て，マウスおよびイヌにおける報告 $[1,9]$ では，いずれ も静脈血の值が, 動脈血の值に対して有意に高くなって おり, 今回の結果とほぼ一致する。しかし一方では, ラ ットにおける右心室および左心室より採血した血液の間 で白血球数の差は見られなかったとの報告あある $[17]$ 。 これは，体内において白血球には循環プールの他に血管 内停滞プールや骨髄内眝蔵プールなどがあり, 採血部 位, 時間, 生理的状態などにより, 白血球数は容易に変 動する[20]ためと考えられる。また，Table 2 に示した ように, 静脈血のリンパ球数は動脈血のリンパ球数に対 して有意に高く，好中球数には有意の差が認められな い。このととより上記の動, 静脈血間の白血球数の差 は, 主にリンパ球数の変動によるあのであることが示唆 された。循環血中におけるリンパ球の動態においては末 梢リンパ器官, リンパ管の存在や, リンパ球の再循環な どがあり, これらの要因が, 動脈血, 静脈血間のリンパ 球の分布にも影響を与えていることが推測される。

また, 本研究では, 開腹手術の後に静脈血, 動脈血の 順に採血したが, 採血に伴う循環血流量の急激な低下
や，開腹手術による胸管リンパ流量の変化などにより， リンパ球の動, 静脈血における分布が生理的状態とは異 なった状態となっていることも考えられる。また, 麻酔 による循環血流量の変化などの影響も考慮に入れる必要 があるあのと思われる。したがって, 本研究において動 脈血と静脈血との間でリンパ球数に有意の差が見られる ことは, これらの多数の要因の相互作用の結果と考えら れる。

Fig. 2-1) のサイトグラム上において, ラット血液中 の紏胞成分は, 紏胞の大きさ之細胞内部の顆粒 密 度 か ら $\mathrm{A}, \mathrm{B}, \mathrm{C}, \mathrm{D}$ 月 4 クラスターに分けられた。とのう ちDは, 細胞の大きさから, 溶血の結果生じた赤血球ゴ 一ストと血小板と考えられる。残りの A, B, Cが白血 球に対応し, リンパ球, 単球, 顆粒球の集団と考えられ る。ラット白血球において細胞の大きさは, リンパ球, 顆粒球, 単球の順で大きくなっており [18], また細胞内 の顆粒密度は, 顆粒球がリンパ球, 単球に比して多いあ のと考えられる。したがって，サイトグラム上で Aがリ ンパ球, Bが単球, Cが顆粒球を表すクラスターである と推定される。

リンパと考えられるクラスターのサブポピュレーショ ンにおける, 各モノクローナル抗体による陽性細胞の比 率に, 動脈血と静脈血の間で有意の差は認められなかっ たことにより, リンパ球各サブポピュレーションには 動, 静脈血間で差はないあのと思われた。

また, W3/25 陽性細胞をへルパーTリンパ球, OX8 陽性細胞をノンヘルパーTリンパ球とすると, このヘル パーノノンヘルパー比においても動脈血と静脈血の間に 
は有意の差は認められない。

以上より, 本研究における白血球数およびリンパ球数 は, 腹部大動脈より採血された動脈血の值が, 後大静脈 より採血された静脈血の值に対して有意に低いが，その 変化はリンパ球サブポピュレーションに影響をあたえて いないものと思われた。しかし動静脈血間の白血球およ び，リンパ球数の差異に関しては，採血方法も吞めて， その原因について今後さらに検討する必要があるものと 思われた。

また本研究においては，モノクローナル抗体とレーザ ーフローサイトメトリーを用いて, ラットのリンパ球サ ブポピュレーションを測定するに当っての諸問題も検討 したので以下に述べる。

本研究において，Fig. 2-1）のサイトグラム上でAク ラスターをリンパ球をあらわす集団としたが，その単一 性については，ヒトリンパ球では各クラスターへの他紐
胞の混入は $1 \%$ 程度であることが 報告されている $[10$, 19]。したがって，ヒトにおいてはサイトグラム上でリ ンパ球をあらわすクラスターの単一性は, 測定上特に問 題はないもの之思われる。しかし，ラットにおいては, 幽球とリンパ球の形態がヒトに比べて類似しているてと が知られている $[18]$ 。したがって，リンパ球をあらわす クラスターへの単球の混入が, ヒトの場合より多い可能 性も考えられ, この点については今後詳紐に検討する必 要があるあのと思われた。

本研究に用いられた各モノクローナル抗体が WistarImamichi ラットにおいても, 各リンパ球サブセットに 対応した抗原を認識してかどうかについては，ヒストグ ラムのプロフィールより検討した。すなわち，本研究に おいて得られた各抗体のヒストグラム（Fig. 3) は，こ れまでに報告されているヒストグラム $[15,16,24]$ とよ く一致しており,したがって Wistar-Imamicni ラット
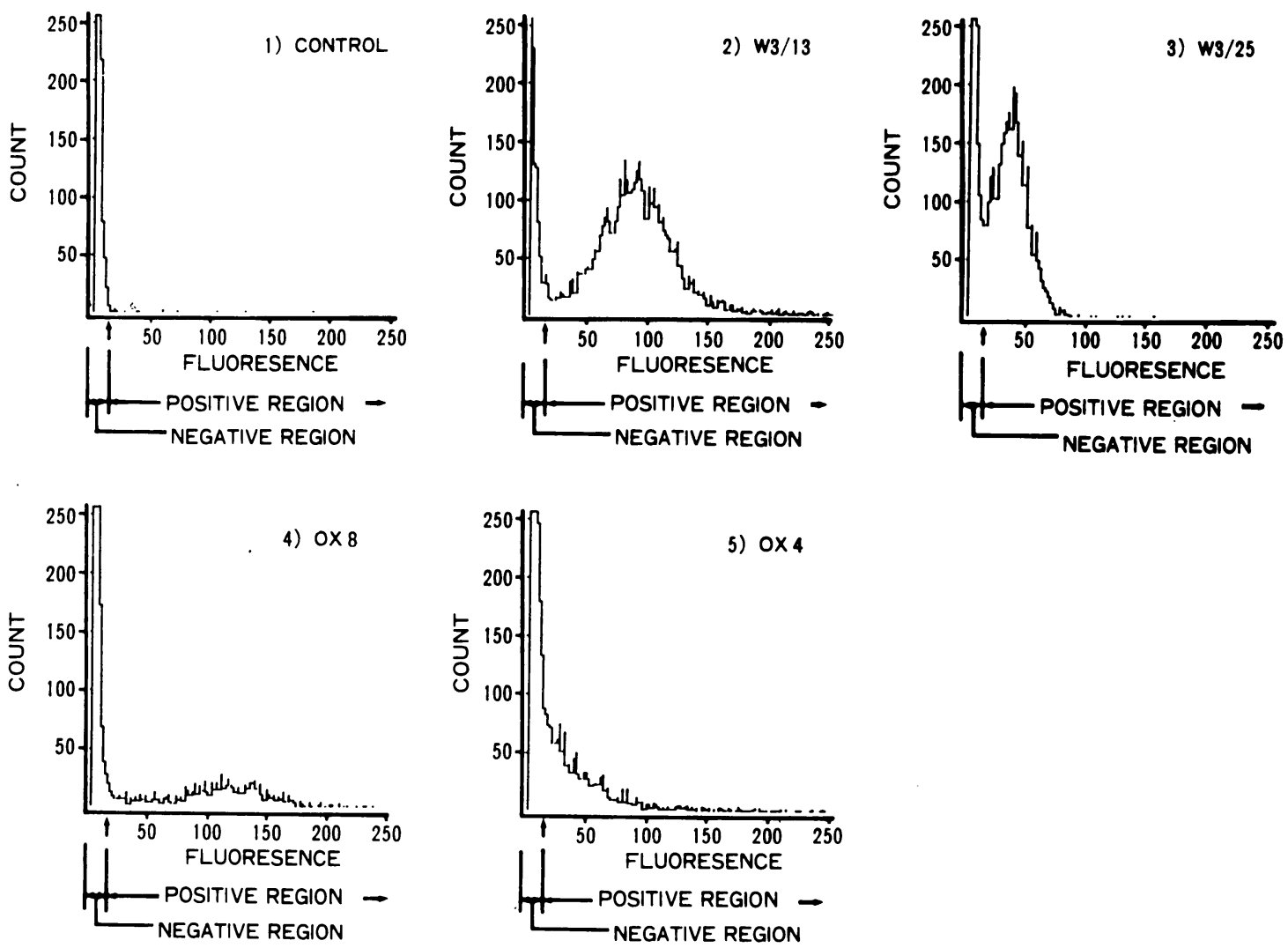

Fig. 3. Fluorescence histograms of Lymphocytes labeled with the indicated monoclonal antibodies. Samples were incubated with indicated monoclonal antibodies. Control labeling was incubated with mouse IgG. The cutoffs for determining the percentage of cells labeled are marked on the profiles with arrows. 
においても，各モノクローナル抗体はそれぞれ対応する リンパ球サブセットに特異的な抗原を認識しているもの と推測された。

オーソ社のスペクトラムIIIでは，前述のように， $90^{\circ}$ 散乱光を利用することによってサイトグラム上で各紐胞 をその形態的特徵から分類することができる。この絬 果, 他のレーザーフローサイトノトリーのように事前に Ficoll-Hypaque 比重遠心法などで単核球を分離する必 要もなく，全血をサンプルとして用い，赤血球を溶血さ せた上で測定することが可能となっている。しかし，ラ ットにおいては, サンプルの調製に当って従来のヒトや マウスに用いられている方法[19]では, 溶血剂を加えた 後に血球成分が凝集してしまい, サイトグラム上での各 細胞の同定が困難となる場合がある(Fig. 2-2))。そこ で本研究においては, 若干の変更を加え, 前述の方法に てサンプルの調製を行ったところ, 血球成分が凝集する こともなく，良好な結果が得られた。したがって，ラッ トリンパ球サブポピュレーションを測定する場合には, この改良法を用いることが望ましいと考えられる。ただ ししこの方法で行う場合, 溶血後時間を置くとサイトグ ラム上での同定が困難となるので, 溶血剤添加後 $2 \sim 3$ 分で溶血を確認した後ただちに測定する必要があるもの と思われた。

\section{要 約}

Wistar-Imamichi ラットにおいて, 動脈血と静脈血 の血液学的性状を比較するとともに, リンパ球サブポピ ユレーションの比較を行った。材料には, 腹部大動脈お よび後大静脈より採血された血液を用いた。リンパ球サ ブセットの同定には，各サブセットに特異的な膜表面糖 蛋白質を抗原決定基とする 4 種類のモノクローナル抗体 を用いた。これらのモノクローナル抗体によって, 各末

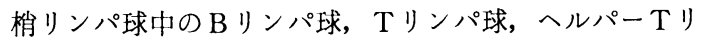
ンパ球, サプレッサーおよび細胞障害性 Tリンパ球の各 サブセットを同定し, そのポピュレーションを,レーザ ーフローサイトメトリーシステムを用いて測定した。血 液学的測定において, 動脈血, 静脈血間に有意の差があ ったのは, 白血球数とへモグロビン濃度であった。その うち, 白血球数の差は主にリンパ球数の違いによるもの と思われた。しかし，各モノクローナル抗体による，リ ンパ球中の陽性細胞の比率には有意の差は認められなか った。以上の成績より，Wistar-Imamichi ラットにお いて動脈血, 静脈血間に見られた白血球数の違いは，末
佾血におけるリンパ球サブポピュレーションの違いによ るものではないことで示唆された。

\section{文献}

[1] Ambrous, C. M., and Ambrous, J. L. (1959). Regulation of the leukocyte level. Ann. N. Y. Acad. Sci., 77, 445-486.

[2] Barclay, A. N. (1981). The localization of poluation of lymphocytes defined by monoclonal antibodies in rat lymphoid tissues. Immunology., 42, 593-601.

[ 3 ] Brideau, R. J., Carter, P. B., McMaster, W. R., Mason, D. W., and Williams, A. F. (1980). Two subsets of rat $\mathrm{T}$ lymphocytes defined with monoclonal antibody. Eur. J. Immunol., 10, 609-615.

[4] Cantor, H., and Boyse, E. A. (1975). Functional subclass of T-lymphocytes bearing different Ly antigens. J. Exp. Med., 141, 1376-1389.

[ 5 ] Cantor, H., Shen, F. W., and Boyse, E. A. (1976). Separatson of helper $\mathrm{T}$ cells from suppressor $\mathrm{T}$ cells expressing different Ly components. II. J. Exp. Med., 143, 1391-1401.

[6] Cantrell, D. A., Robins, R. A., Brooks, C. G., and Baldwin, R. W. (1982). Phenotype of rat natural killer cells defined by monoclonal antibodies marking rat lymphocyte subsets. Immunology, 45, 97-103.

[ 7 ] Dallman, M. J., Mason, D. W., and Webb, M. (1982). Role of host and donor cells in the rejection of skin allografts by $\mathrm{T}$ cell deprived rats injected with syngenic T cells. Eur. J. Immunol., 12, 511-518.

[8] Doell, B. H., and Hegarty, P. V. J. (1970). The hemoglobin concentration of peripheral and central blood of the laboratory rat. Bri. J. Hae matol., 18, 503-509.

[9] Goldie, H., Jones, A. M., Ryan, H., and Simpson, M. (1954). Leukocyte counts in the Blood from the tail and the heart of the mouse. Science, 119, 353-354.

[10] Ip, S. H., Rittershaus, C. W., Healey, K. W., Struzziero, C. C. Hoffman, R. A., and Hansen, P. W. (1982). Rapid Enumeration of T lymphocytes by a flow-cytometric immunofluorescence method. Clin. Chem. 28, 1905-1909.

[11] Ishii, Y., Matsumura, A., Yuasa, H., Narita, H., Takami, T., and Kikuchi, K. (1983). Two distinct antigenic markers for rat thymus and $\mathrm{T}$ cells defined by monoclonal antibodies. Inmunology, 48, 743-755.

[12］伊藤喜久 (1983)。レーザーのフローサイトメトリーへの 応用. 臨床検查, 27, 985-991.

［13］伊藤喜久 - 原田弘智・河合 忠・中野康平 (1983)，レー ザーフローサイトメトリーによる T 細胞サブセットの自 動解析. 臨床検査, 27, 817-820.

[14] Köhler, G., and Milstein, C. (1975). Continuous cultures of fused cells secreting antibody of predefind spcificity. Natur, 256, 495-497.

[15] Mason, D. W., Arthur, R. P., Dallman, M. J., Green, J. R., Spickett, G. P., and Thomas, M. L. (1983). Function of rat T-lymphocyte subsets 
isolated by monoclonal antibodies. Immunol. Rev., 74, 57-82.

[16] McMaster, W. R., and Williams, A. F. (1979). Identification of Ia glycoproteins in rat thymus and puricfiation from rat spleen. Eur. J. Immunol., 9, 426-433.

[17] Quimby, F. H., and Goff, L. G. (1952). Effect of source of blood sample on total white cell count of the rat. Am. J. Physiol., 170, 196-170.

[18] Ringer, D. H., and Dabich, L. (1979). Hematology and clinical biochemistry. In The Laboratory Rat (volume I), pp. 105-121. Baker, H. J., Lindsey, J. R., and Weisbroth, S. H. (edit.), Academic Press Inc., New York.

[19］佐藤三郎 (1984). リンパ球サブセット解析のための周辺 機器の開発. 最新医学, 39, 106-110.

[20] Schalm, O. W., Jain, N. C., and Carrol, E. J. (1975). Veterinary Hematology. pp. 471-538, Lea
\& Febiger, Philadelphia.

[21] Upton, P. K., and Morgan, D. J. (1975). The effect of sampling technique on some blood parameters in the rat. Lab. Anim., 9, 85-91.

[22] 若藤靖匡 - 外尾亮治 - 天尾弘実・高橋和明・今道友則 (1984). Wistar-Imamichi rat の SPF 化に伴う産仔 数の增加之胚・胎仔の損失現象について。実験動物， 33, 165-171.

[23] White, R. A. H., Mason, D. W., Williams, A. F., Galfre, G., and Milstein, C. (1978). T lymphocyte heterogeneity in the rat: separation of functional sabpopulation using a monoclonal antibody. J. Exp. Med., 148, 664-673.

[24] Williams, A. F., Galfre, G., and Milstein, C. (1977). Analysis of cell surface by xenogeneic myeloma-hybrid antibodies. Differentiation antigens of rat lymphocytes. Cell, 12, 663-673. 